\title{
SOSIALISASI PENDIDIKAN KARAKTER BERBASIS BUDAYA PADA ANAK-ANAK DENGAN MEDIA VIDEO
}

\author{
Uni Ekowati ${ }^{{ }^{*}}$, Wellem Nggonggoek², Susilo Setyo Utomo ${ }^{3}$ \\ ${ }^{1 *}$ Program Studi Antropologi Sosial, Universitas Muhammadiyah Kupang \\ ${ }^{2}$ Program Studi Antropologi Sosial, Universitas Muhammadiyah Kupang \\ ${ }^{3}$ Program Studi Pendidikan Sejarah, Universitas Nusa Cendana \\ ${ }^{*}$ Corresponding author: \\ E-mail : uniekowati25@gmail.com
}

Diterima 26 April 2019, Disetujui 3 Mei 2019

\begin{abstract}
ABSTRAK
Pengabdian kepada Masyarakat dilaksanakan di TPQ di Mushola Baumata yang merupakan tempat belajar Al Quran bagi anak-anak yang berada di Baumata Barat Kecamatan Taebenu Kabupaten Kupang. Peran keluarga terutama orang tua di daerah Baumata Barat dalam mengembangkan karakter anak-anak mereka belum sepenuhnya maksimal sehingga perkembangan karakter anak dalam bidang spiritual, emosional dan intelektual belum begitu seimbang dan selaras. Selain itu banyak anak-anak yang ternyata sudah tidak mengenal atau belum mengenal nilai-nilai sosial budaya yang ada dan ternyata mengandung nilai-nilai karakter yang luhur. Tujuan dari pelaksanaan kegiatan pengabdian masyarakat ini yaitu munculnya karakter yang berbasis budaya/kearifan lokal dari anak-anak TPQ tersebut karena dengan hal-hal tersebut kami berharap anak-anak mampu bersaing dengan individu lain dalam berbagai konteks. Untuk menumbuhkan karakter tersebut pada anak-anak di TPQ diperlukan kegiatan secara bertahap agar tercipta kebiasaan yang teratur selain belajar membaca Al Qur'an. Metode kegiatan pengabdian ini yaitu metode kajian kualitatif deskriptif. Hasil kegiatan menunjukkan bahwa penayangan media video berbais budaya pada anak-anak TPQ ternyata dapat membantu anak-anak lebih mudah memahami nilai-nilai karakter sesuai dengan budaya yang mereka miliki. Pendidikan karakter menjadi sangat penting terutama anak-anak karena karakter menjadi dasar seorang individu untuk bersaing di masa yang akan datang
\end{abstract}

Kata Kunci: Pendidikan Karakter, Budaya, Media Video

\begin{abstract}
Community service was carried out at TPQ in Baumata Mosque, which is a learning place of Holy Quran for children in West Baumata, Taebenu District, Kupang Regency. The role of families, especially parents in the West Baumata area in developing the character of their children is not fully maximized so that the development of children's character in the spiritual, emotional and intellectual fields has not been balanced and harmonious. In addition, many children are apparently not familiar with or do not know the existing of socio-cultural values which evidently contain noble character values. The purpose of implementing this community service activity is the emergence of culture-based/local wisdom characters from the TPQ children because with these things we hope that children can compete with other individuals in various contexts. To grow these characters in children at the TPQ, stages activities are needed to create regular habits besides in learning to read the Qur'an. This method of service activities is a descriptive qualitative study. The results of the activity showed that the display of cultural media video on TPQ children turned out to help children easily more understand the character values in accordance with the culture they have. Character education is essential especially for children since a character becomes the basis of an individual to compete in the future.
\end{abstract}

Keywords: Character Education, Culture, Video Media

\section{PENDAHULUAN}

Karakter merupakan watak, tabiat, akhlak, atau kepribadian seseorang yang terbentuk dari hasil internalisasi berbagai kebajikan (virtues) yang diyakininya dan digunakannya sebagai landasan untuk cara pandang, berpikir, bersikap, dan bertindak. Kebajikan terdiri atas sejumlah nilai, moral, dan norma seperti jujur, berani bertindak, dapat dipercaya, hormat kepada orang lain, dan sebagainya. Interaksi seseorang dengan orang lain menumbuhkan karakter masyarakat dan karakter bangsa.

Penanaman nilai-nilai akhlak, moral dan budi pekerti tertuang dalam Undang-undang Republik Indonesia No. 20 tahun 2003 tentang system pendidikan nasional pada Pasal 3 , yang 
menyebutkan bahwa pendidikan nasional berfungsi mengembangkan kemampuan dan membentuk karakter serta peradaban bangsa yang bermartabat dalam rangka mencerdaskan kehidupan bangsa. Pendidikan nasional bertujuan untuk berkembangnya potensi peserta didik agar menjadi manusia yang beriman dan bertakwa kepada Tuhan Yang Maha Esa, berakhlak mulia, sehat, berilmu, cakap, kreatif, mandiri, dan menjadi warga negara yang demokratis serta bertanggung jawab. Hal tersebut berkaitan dengan pembentukan karakter peserta didik sehingga mampu bersaing, beretika, bermoral, sopan santun dan berinteraksi dengan masyarakat

Undang-undang Republik Indonesia No. 20 tahun 2003 tersebut harus menjadi dasar pijakan utama dalam mendesain, melaksanakan dan mengevaluasi system pendidikan nasional. Bangsa yang maju adalah bangsa yang memiliki karakter unggul dan berkualitas. Pendidikan karakter menjadi sangat penting bagi bangsa Indonesia untuk menyiapkan generasi dalam persaingan global.

Pendidikan karakter adalah pendidikan untuk membentuk kepribadian seseorang melalui pendidikan budi pekerti, yang hasilnya terlihat dalam tindakan nyata seseorang, yaitu tingkah laku yang baik, jujur, bertanggung jawab, menghormati hak orang lain, kerja keras, dan sebagainya (Lickona, 1992:12). Menurutnya keberhasilan pendidikan karakter dimulai dengan pemahaman karakter yang baik, mencintainya, dan pelaksanaan atau peneladanan atas karakter baik itu. Menurut Thomas Lickona tanpa ketiga aspek ini, maka pendidikan karakter tidak akan efektif. Pendidikan karakter yang diterapkan secara sistematis, dan berkelanjutan, seorang anak akan menjadi cerdas emosinya. Sebab kecerdasan emosi ini menjadi bekal penting dalam mempersiapkan masa depan anak dan mampu menghadapi segala macam tantangan.

Pendidikan karakter yang merupakan upaya pembangunan watak, tabiat, akhlak, atau budi pekerti seorang anak manusia untuk hidup lebih baik, lebih manusiawi, dan lebih berperikemanusiaan. Di dalam studi kebudayaan, istilah itu digunakan untuk nilai-nilai yang senantiasa melandasi berbagai kegiatan suatu masyarakat di dalam kehidupan hidup kesehariannya. Dengan kata lain dengan menganalisis kegiatan hidup sehari-hari seperti ketulusan hati, kejujuran, keutuhan, kedewasaan, kapasitas mental yang dapat atau layak dipercaya pada masyarakat orang tua yang masih sederhana seperti di daerah pedesaan atau diperkotaan dapat diidentifikasi nilai-nilai jati diri yang melandasi kegiatan-kegiatan hidup itu.

Kehidupan masyarakat dalam waktu yang panjang bertumpu pada masyarakat lokal.
Kebersamaan, consensus, demokratis menjadi praktik keseharian. Gotong royong yang diiringi keikhlasan mewarnai praktik kehidupan masyarakat. Namun, dalam perjalanan selanjutnya terutama sejak kehadiran penguasa Kolonial atau masuknya kebudayaan asing, lama kelamaan tergeserlah nilai-nilai lokal dalam praktik keseharian.

Mengingat pentingnya pendidikan karakter dalam interaksi sosial masyarakat maka dari itu perlunya penanaman pendidikan karakter sejak usia dini. Proses pengembangan nilai-nilai budaya dan karakter bangsa adalah sebuah proses panjang dimulai dari usia dini. Pendidikan karakter dibentuk pada lingkungan internal maupun eksternal seorang anak. Pendidikan karakter pada lingkungan internal dimulai dari lingkungan keluarga. Sedangkan pendidikan karakter pada lingkungan eksternal meliputi masyarakat dan lingkungan sekolah. Maka dari itu harus adanya kerjasama antara pihak di dalam lingkungan ekternal maupun internal.

TPQ di Mushola Baumata adalah tempat belajar Al Quran bagi anak-anak yang berada di Baumata Barat Kecamatan Taebenu Kabupaten Kupang. Peran keluarga terutama orang tua dalam mengembangkan karakter anak-anak mereka belum sepenuhnya maksimal sehingga perkembangan karakter anak dalam bidang spiritual, emosional dan intelektual belum begitu diperhatikan sehingga. Selain itu banyak anakanak yang ternyata sudah tidak mengenal atau belum mengenal nilai-nilai sosial budaya yang ada pada mereka. Padahal nilai-nilai sosial budaya yang ada sebenarnya mengandung nilai-nilai positif termasuk memiliki kontribusi terhadap pembentukan karakter yang dapat dijadikan pedoman dalam kehidupan sehari-hari bagi anakanak. Dengan demikian, pembelajaran nilai-nilai karakter perlu untuk disosialisasikan atau diinternalisasikan agar anak-anak tetap mengenal budaya mereka dan memiliki karakter yang baik sejak dini.

Tujuan utama membuat program ini adalah munculnya karakter yang berbasis budaya/kearifan lokal dari anak-anak TPQ tersebut karena dengan hal-hal tersebut kami berharap anak-anak mampu bersaing dengan individu lain dalam berbagai konteks. Untuk menumbuhkan karakter tersebut pada anak-anak di TPQ diperlukan kegiatan secara bertahap agar tercipta kebiasaan yang teratur selain belajar membaca Al Qur'an.

Berdasarkan hal di atas, kami menawarkan solusi dengan menayangkan video anak-anak berbasis budaya yang di dalamnya memuat nilai-nilai karakter sebagai salahsatu sarana dalam mengembangkan karakter pada anak-anak TPQ. Dengan pertimbangan bahwa 
anak-anak lebih menyukai media audiovisual karena dianggap menarik dan tidak membosankan. Dengan media video tersebut mereka dapat melihat contoh-contoh keteladanan yang dapat diambil nilai karakternya. Selain itu kami selingi dengan beberapa permainan bukan pendidikan formal seperti yang didapat anak-anak di sekolah.

Target luaran yang ingin dicapai adalah menyediakan informasi yang berguna tentang pendidikan karakter pada anak-anak TPQ. Selain mereka pandai mengaji/ membaca Al Qur'an mereka dapat berakhlak baik baik di dalam keluarga, masyarakat maupun di sekolah.

Proses internalisasi pendidikan karakter pada anak-anak dapat dilakukan dengan model pembelajaran berbasis budaya lokal. Sedangkan media yang menarik untuk anak-anak dalam proses internalisasi karakter dapat dilakukan dengan media video anak-anak agar pembelajaran tersebut menjadi menarik dan menyenangkan sesuai usia mereka.

Pengembangan model pembelajaran dimaksud dalam kerangka membantu generasi muda terutama anak-anak agar mampu mempelajari berbagai ilmu pengetahuan tanpa lupa membangun karakter dirinya dan bangsanya, maka diperlukan suatu target yang terukur baik secara kuantitatif maupun kualitatif. Dengan demikian target luaran yang diharapkan melalui kegiatan ini dapat dirumuskan sebagai berikut:

1. Anak-anak TPQ dapat mengembangkan karakter, selain belajar membaca Al Quran

2. Anak-anak TPQ dapat mengaplikasikan pengalaman dan ilmu yang kami berikan dengan sarana video berbasis budaya, selama maupun setelah kegiatan ini berlangsung.

3. Anak-anak mengenal kekayaan dan nilai-nilai sosial budaya yang mereka miliki dan mengandung nilai-nilai karakter di dalamnya yang dapat diterapkan dalam kehidupan sehari-hari.

4. Anak-anak TPQ dapat mencintai dan melestarikan budaya mereka.

\section{METODE KAJIAN}

Metode kegiatan pengabdian ini yaitu metode kajian kualitatif deskriptif. Metode ini merupakan hasil gagasan dari penulis yang kemudian dikembangkan berdasarkan teori-teori yang sesuai dengan variabel penelitian. Untuk merealisasikan kegiatan pengabdian kepada masyarakat agar sasaran tercapai dengan langkah sebagai berikut:

a. Memberikan materi dengan menggunakan media video berbasis budaya seperti tentang kegiatan keseharian dan acaraacara budaya.

b. Mengundang anak-anak yang ada di TPQ desa Baumata Barat dan perwakilan bapak/ibu setempat

c. Permainan anak-anak (budaya)

d. Diskusi dan dialog

e. Tempat kegiatan: di Aula Kantor desa Baumata Kecamatan Tebenu Kabupaten Kupang

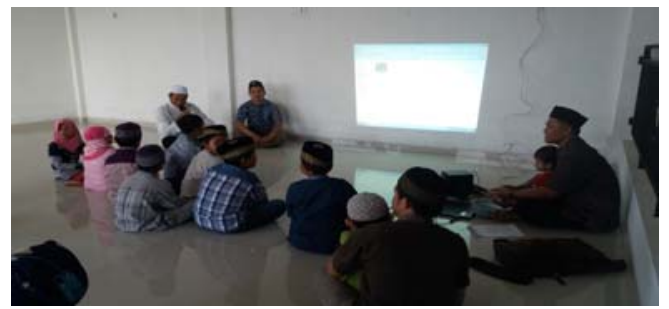

Gambar 1. Kegiatan Diskusi dan Dialog (Sumber: Dokumentasi Pribadi, 2018).

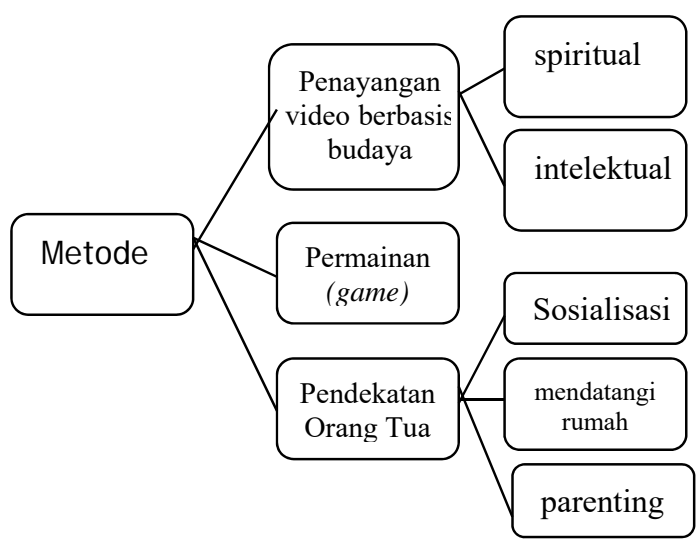

Gambar 2. Metode Pengabdian

\section{HASIL DAN PEMBAHASAN}

Pendidikan karakter adalah pendidikan untuk membentuk kepribadian seseorang melalui pendidikan budi pekerti, yang hasilnya terlihat dalam tindakan nyata seseorang, yaitu tingkah laku yang baik, jujur, bertanggung jawab, menghormati hak orang lain, kerja keras, dan sebagainya (Lickona, 1992:12) Thomas Lickona mendefinisikan orang yang berkarakter sebagai sifat alami seseorang dalam merespon situasi secara bermoral yang dimanifestasikan dalam tindakan nyata melalui tingkah laku yang baik, jujur, bertanggung jawab, menghormati orang lain dan karakter mulia lainnya. 
Video berbasis budaya dapat menjadi sarana bagi anak-anak dalam mengembangkan karakter

Pendidikan karakter berbasis budaya menjadi salahsatu solusi alternative bagi pelaksanaan pendidikan karakter sesuai dengan keunggulan lokal yang dimiliki masing-masing daerah dalam mencegah dan mengurangi pergeseran nilai kemanusiaan akibat adanya arus globalisasi. Hal ini sejalan dengan fungsi pendidikan nasional yaitu mengembangkan kemampuan dan membentuk watak serta peradaban bangsa yang bermartabat dalam rangka mencerdaskan kehidupan bangsa, dan untuk mengembangkan potensi peserta didik agar menjadi manusia manusia yang beriman dan bertakwa kepada Tuhan Yang Maha Esa, Berakhlak mulia, sehat, berilmu, cakap kreatif, mandiri dan menjadi warga Negara yang demokratis serta bertanggung jawab. Selain itu diarahkan untuk membentuk watak atau karakter bangsa, sehingga mampu menjadi bangsa yang beradab dan bermartabat luhur serta mampu menjadi bangsa yang memiliki keunggulan tertentu dibanding bangsa-bangsa lain.

Penayangan media video berbais budaya pada anak-anak TPQ ternyata dapat membantu anak-anak lebih mudah memahami nilai-nilai karakter. Video yang menjadi salahsatu media penanaman pendidikan karakter disukai anakanak. Pesan-pesan moral yang ada dalam setiap video yang mengandung budaya sehari mereka sehingga kontekstual dan mudah dimengerti. Pendidikan karakter menjadi sangat penting terutama anak-anak karena karakter menjadi dasar seorang individu untuk bersaing di masa yang akan datang. Cerdas secara intelektual tidak menjamin seseorang untuk sukses, karena sukses merupakan kombinasi dari kecerdasan intektual, emosional dan spiritual. Hal tersebut tentu tidak terlepas dari peran serta orang tua yang merupakan sosialisasi paling utama bagi anakanak. Untuk itu dalam penelitian ini diadakan sosialisasi juga terhadap orang tua tentang pentingnya pendidikan karakter bagi anak.

Selain menayangkan video berbasis budaya sebagai media penghantar dalam penanaman karakter bagi anak, kami juga memberikan pelatihan parenting untuk orang tua dari peserta didik, hal ini dilakukan untuk menanamkan kesadaran bahwa anak adalah tanggung jawab dan amanah yang harus dijaga. Selain itu kami juga mengajarkan bagaimana perilaku yang baik yang perlu ditanamkan pada anak-anak dalam kehidupan sehari-hari.

Pendidikan karakter dapat ditanamkan tidak hanya ditanamkan secara formal disekolah tetapi perlu ditanamkan juga diluar sekolah (informal), sehingga diharapkan dengan adanya keseimbangan penanaman pendidikan karakter baik informal maupun formal anak-anak tidak hanya cerdas dan pandai dalam bidang akademik tetapi juga memiliki dan menjunjung tinggi nilainilai budaya yang ada sebagai jati diri dan keunggulan bangsa. Berdasarkan hasil analisis dan pembahasan maka dapat disimpulkan bahwa media berbasis budaya dapat menjadi sarana bagi anak-anak dalam mengembangkan karakter.

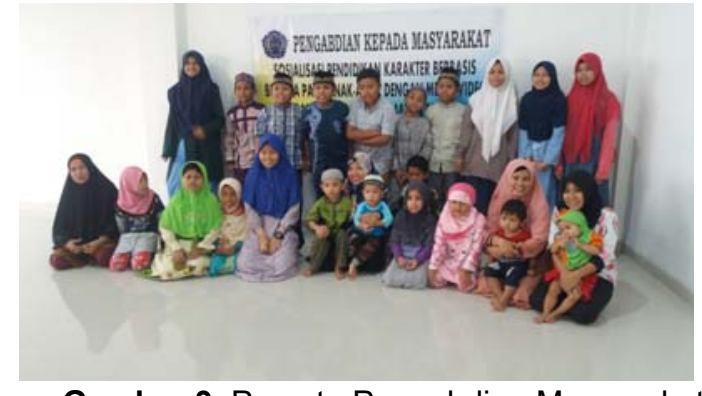

Gambar 3. Peserta Pengabdian Masyarakat (Sumber: Dokumentasi Pribadi, 2018)

\section{Media video berbasis budaya ini dapat diaplikasikan anak-anak}

Pembentukan karakter diibaratkan sebagai pembentukan seseorang menjadi binaragawan yang memerlukan "latihan otot-otot akhlak secara terus menerus dan berkelanjutan agar menjadi kokoh dan kuat. Pada dasarnya, anak-anak yang memiliki kualitas karakter rendah adalah anak yang tingkat perkembangan emosisosialnya rendah, sehingga anak beresiko besar mengalami kesulitan belajar, berinteraksi sosial, dan tidak mampu mengontrol diri. Mengingat pentingnya penanaman karakter pada usia dini, maka pendidikan karakter merupakan hal yang sangat penting untuk dilaksanakan.

Penanaman nilai-nilai karakter sangat memerlukan pembiasaan sejak dini termasuk pada tingkatan anak-anak. Anak mulai dibiasakan mengenal perilaku mana yang baik dan mana yang buruk, mana yang boleh dilakukan dan mana yang tidak boleh dilakukan, sehingga diharapkan pada gilirannya menjadi sebuah kebiasaan. Perlahanlahan sikap dan nilai-nilai yang ditanamkan tersebut akan terinternalisasi ke dalam dirinya dan membentuk kesadaran bersikap dan tindakan sampai usia dewasa

Pendidikan karakter yang ditanamkan dengan media video berbasis budaya ini kehidupan sehari-hari ini diharapkan dapat menghasilkan lingkungan yang kondusif bagi anak-anak TPQ Jabal Rahmah bagi pertumbuhan anak dan bekal bagi mereka untuk persaingan dimasa yang akan datang. Hal ini ditunjang pendidikan parenting bagi orang tua dapat meneruskan kebiasaan baik yang akan menunjang keberlangsungan bagi program yang telah kami jalankan bagi putra putri mereka. 
Karakter sebagai suatu 'moral excellence' atau akhlak dibangun di atas berbagai kebajikan (virtues) yang pada gilirannya hanya memiliki makna ketika dilandasi atas nilai-nilai yang berlaku dalam budaya (bangsa). Karakter bangsa Indonesia adalah karakter yang dimiliki warga negara bangsa Indonesia berdasarkan tindakantindakan yang dinilai sebagai suatu kebajikan berdasarkan nilai yang berlaku di masyarakat dan bangsa Indonesia. Oleh karena itu, Pendidikan Budaya dan Karakter Bangsa diarahkan pada upaya mengembangkan nilai-nilai yang mendasari suatu kebajikan sehingga menjadi suatu kepribadian diri warga negara.

Proses pembelajaran Pendidikan Budaya dan Karakter Bangsa dilaksanakan melalui proses belajar aktif. Sesuai dengan prinsip pengembangan nilai harus dilakukan secara aktif oleh anak-anak (dirinya subyek yang akan menerima, menjadikan nilai sebagai miliknya dan menjadikan nilai-nilai yang sudah dipelajarinya sebagai dasar dalam setiap tindakan) maka posisi anak-anak sebagai subyek yang aktif dalam belajar.

Anak-anak TPQ tertarik untuk melihat video berbasis budaya ini dari awal sampai akhir

Pendidikan karakter adalah budi pekerti plus, yaitu yang melibatkan aspek pengetahuan (cognitive), perasaan (feeling) dan tindakan (action). Menurut (Thomas Licona, 1992: 21), tanpa ketiga aspek ini, akan pendidikan karakter tidak akan efektif, dan pelaksanaannya pun harus dilakukan sistematis dan berkelanjutan. Dengan pendidikan karakter, seorang anak akan menjadi cerdas emosinya. Kecerdasan emosi adalah bekal terpenting dalam mempersiapkan anak menyongsong masa depan, karena dengannya seseorang akan dapat berhasil dalam menghadapi segala macam tantangan termasuk berhasil dalam bidang akademis.

Media video yang digunakan dalam memberikan pendidikan karakter ternyata banyak disukai anak-anak. Hal ini dibuktikan dengan besarnya antusiasme anak-anak TPQ dalam menonton video yang ditayangkan. Mereka tampak serius mengamati semua yang ada divideo. Bahkan mereka tampak tertawa karena didalam video mengandung nilai humor yang di dalamnya terselip pesan moral di dalamnya. Dengan demikian memang diperlukan metode dan media yang tepat agar pendidikan karakter mudah di terima oleh anak-anak.

Anak-anak tampak ceria dan senang setelah penayangan video dan diberikan kuis untuk dijawab. Soal-soal kuis diberikan sesuai dengan pesan -pesan karakter dan moral yang ada di dalam video dan budaya mereka. Banyaknya anak-anak yang antusias dalam menjawab pertanyaan bahkan berebut menjawab. Permainan dan kuis tampak seru dan menyenangkan. Anak-anak pun menjawab dengan benar dan diberikan reward atau hadiahnya.

Setelah semua anak-anak mengikuti terus disimpulkan bahwa pendidikan karakter itu sangatlah penting dan perlu diberikan sejak dini agar mereka memiliki katakter yang baik dan kuat dalam menghadapi era global dan tidak tercabut dari akar budaya mereka. Anak-anak TPQ diharapkan dapat mengaplikasikan semua pendidikan dan pesan moral yang telah diberikan agar mereka cerdas secara spiritual, akademik dan emosional. Dalam kehidupan sehari-hari pun mereka dapat menentukan mana yang baik dan mana yang tidak baik.

\section{SIMPULAN DAN SARAN}

Berdasarkan hasil di atas dapat disimpulkan bahwa menayangkan video berbasis budaya yang di dalamnya memuat nilai-nilai karakter sebagai salahsatu sarana dalam mengembangkan karakter pada anak-anak TPQ. Dengan pertimbangan bahwa anak-anak lebih menyukai media audiovisual karena dianggap menarik dan tidak membosankan. Dengan media video tersebut mereka dapat melihat contohcontoh keteladanan yang dapat diambil nilai karakternya. Selain itu kami selingi dengan beberapa permainan bukan pendidikan formal seperti yang didapat anak-anak di sekolah. Untuk itulah media video dapat dijadikan alternative atau solusi dalam memberikan pendidikan karakter pada anak-anak.

\section{DAFTAR RUJUKAN}

Arief S. Sadiman, et al. 2009. Media Pendidikan:pengertian,pengembangan dan pemanfataannya. Jakarta: Rajawali Pers.

Arsyad, Azhar. $2006 . \quad$ Media Pembelajaran.Jakarta:PT.Raja Grafindo.

Koesoema, Doni, A. 2010. Pendidikan Karakter Strategi Mendidik Anak di Zaman Global. Jakarta: Grasindo.

Lickona, Thomas. 1992. Educating For Character How Our School Can Teach Respect and Responsibility. New York: Bantam Books.

Pusat Pengembangan Kurikulum. 2011. Pedoman Pengembangan Pendidikan Budaya dan Karakter Bangsa bagi Sekolah. Jakarta: Kementerian Pendidikan Nasional.

Moleong, J. Lexy. 2000. Metode Penelitian Kualitatif. Bandung: PT Remaja Rosda Karya.

Sutopo, H. B. 2006. Metode Penelitian kualitatif. Surakarta: Universitas Sebelas Maret Press. 